Vorontsova, T., Ponomarenko, V., Khomych, O., Harbuziuk, I., Andruk, A. (2019). Nova ukrainska shkola: metodyka navchannia intehrovanoho kursu «Ia doslidzhuiu svit» u 1-2 klasakh zakladiv zahalnoi serednoi osvity na zasadakh kompetentnisnoho pidkhodu [New Ukrainian School: methods of teaching the integrated course «I explore the world» in 1-2 grades of general secondary education on the basis of the competence approach]. Kyiv: Alaton. [in Ukrainian].

Bolshakova, I. (2018). Intehrovanyi kurs «Ia doslidzhuiu svit». Navchannia na osnovi zapytiv [Integrated course «I Explore the World». Learning based on queries]. URL: https://www.youtube.com/watch?v=4S-VXV7Lw6M(data zvernennia: 12.01.2020). [in Ukrainian].
Sharan, O., Chopyk, S. (2019). Zdoroviazberezhuvalni tekhnolohii naurokakhmatematyky ta informatyky u pochatkovii shkoli [Health Technologies in Elementary School Math and Computer Science Lessons]. Rozvytok suchasnoi osvity i nauky: rezultaty, problemy, perspektyvy. S. 124-126. [in Ukrainian].

Bibik, N., Savchenko, O., Martynenko, V., Tsymbalaru, A.(2017). Orhanizatsi iniformynavchannia u pochatkovii shkoli [Organizational forms of education in primary school]. Kyiv: Pedahohichna dumka. [in Ukrainian].

Barna, O., Hrushchynska, I., Morze N., Khytra, Z.(2019). Ya doslidzhuiu svit: skladovi uspikhu [I explore the world: the components of success]: metodychnyi posibnyk do intehrovanoho kursu. Kyiv: Orion. [in Ukrainian].

Дата надходження до редакиії: 16.01.2021 p.

\section{Iryna ZVARYCH,}

Doctor of Sciences in Pedagogics, Professor,

Professor at the Department of

Foreign Philology and Translation,

Kyiv National University of Trade and Economics,

Kyiv, Ukraine

ORCID: 0000-0003-0715-9551

e-mail:Iryna.Zvarych7@gmail.com

\title{
THE DISTANCE STUDYING SYSTEM DISADVANTAGES AT HIGHER LEARNING INSTITUTIONS OF UKRAINE
}

\begin{abstract}
This article deals with the imperfection of the distance learning system at higher learning institutions; attention is focused on detailed coverage of each shortcoming and the positive advantages of distance education are revealed; the necessity for oral communication and accreditation of academic disciplines is emphasized; research methods, in particular inductive and deductive are covered, due to these methods the theoretical understanding of the distance learning system was carried out.

It has been highlighted the disadvantages and advantages of the distance learning system in higher education institutions, in particular, outlines the importance of «live» communication and accreditation of academic disciplines. The research methods are characterized. Inductive and deductive, due to which the theoretical comprehension of the distance learning system is carried out. It was used in order to cover the selected tasks, method of analysis of sources and materials. Among which monographic studies, publications and regulations.

It has been proved that the methodological basis of the study are the initial provisions of philosophy on dialectical relationships, the interdependence of phenomena
\end{abstract}

and processes of social and pedagogical activities, the role of the individual in the development of its material and spiritual foundations.

Distance learning impresses more people for education, including higher education, but there are a number of shortcomings that need to be addressed in order to address them and find a compromise for successful distance learning. It has been considered the following disadvantages of distance learning: restrictions on direct communication between students and teachers, lack of direct access of students to the teacher, constant self-motivation of students, isolation of distance learning, limitation of available special courses to specialize, the need for constant reliable access to new learning technologies and Internet, mandatory accreditation of distance learning educational programs, restrictions on employment, unforeseen additional costs for distance education, restrictions on improving the skills of oral communication of students.

Key words: distance education, distance system, higher learning institution, imperfection, shortcomings, system of education. 
Ірина ЗВАРИЧ,

доктор педагогічних наук, професор,

професор кафедри іноземної філології та перекладу

Київського національного

торговельно-економічного університету,

м. Київ, Украӥна

ORCID: 0000-0003-0715-9551

e-mail:Iryna.Zvarych7@gmail.com

\section{НЕДОЛІКИ ДИСТАНЦЙНОЇ СИСТЕМИ НАВЧАННЯ У ЗАКЛАДАХ ВИЩОЇ ОСВІТИ УКРАЇНИ}

\begin{abstract}
Анотація. У статті висвітлено недоліки та переваги дистанційної форми навчання у закладах вищої освіти, зокрема окреслено важливість «живого» спілкування. Схарактеризовано методи дослідження, передусім індуктивний та дедуктивний, завдяки яким здійснюється теоретичне осмислення дистанційноі системи навчання. Із метою висвітлення виокремлених завдань використано метод аналізу джерел і матеріалів, серед яких -монографічні дослідження, публікаиіі та положення.
\end{abstract}

Доведено, що методологічною основою дослідження є вихідні положення філософії про діалектичні взаємозв'язки, взаємозалежність явищ і процесів соціально-педагогічної діяльності, роль особистості у розвитку ї̈ матеріальних і духовних основ.

Дистанційне навчання імпонує значній кількості здобувачів освіти, зокрема і вищої, проте існує низка недоліків, на які варто звернути увагу, аби усунути їх та знайти компроміс для успішного вивчення навчальної дисцииліни у дистанційному режимі. Розглянуто такі недоліки дистанційної системи навчання: обмеження безпосереднього спілкування студентів із педагогами, відсутність прямого доступу студентів до викладача, постійна самомотивація студентів, ізольованість дистаниіийого навчання, обмеження доступних навчальних спецкурсів із метою оволодіння спеціалізаиією, необхідність постійного й надійного доступу до новітніх технологій навчання та інтернет-мережі, обов'язкова акредитаиія освітніх програм із дистаниійного навчання, обмеження щзодо працевлаштування, удосконалення вмінь $і$ навичок усного спілкування студентів, непередбачені додаткові витрати на дистанційну освіту.

Ключові слова: заклад вищої освіти, дистанційна система, дистаниійна освіта, недосконалість, недоліки, система навчання.

Statement of the problem. The existing education system, with all its attempts to reform and modernize, has been unable to respond in a timely and prompt manner to the significant scientific discoveries that have been made over the past twentieth century. The students of Universities and secondary schools are working on updated programs, textbooks, which have many shortcomings, and the adult population, including teachers, faced significant problems because they, based on previously acquired knowledge, were unprepared to implement new discoveries, which gave modern science: to master the latest technologies, including computers and distance learning platforms, to carry out the learning process at a distance. Most educators have repeatedly had difficulty with technical equipment, computer literacy, to provide accessible educational information for their students and to receive timely feedback.

Changes in society, in particular the global pandemic, have led to the active start of distance learning in higher and secondary education, and thus forced teachers, lecturers, students and parents to improve the technical means of learning, transfer educational information and get results, perception and mastery of educational material in a particular discipline, coverage of project presentations

Analysis of research and publications. This problem is studied by I. G. Vlasenko. The idea of the imperfection of the distance learning system at higher learning institutions was discovered by V. Y. Bykov, O. O. Grytsenchuk, Y. O. Zhuk.

The methodological basis of the study is the initial provisions of philosophy on the dialectical relationship, the interdependence of phenomena and processes of sociopedagogical activities, the role of the individual in the development of its material and spiritual foundations.

The aim of research is to focus on the implementation of the distant learning system at Higher Learning Institutions, underling the distant system of education with its drawbacks.

Presentation of the main study material. A lot of people adore the distance learning higher education, but there are a number of shortcomings that need to be addressed in order to address them and find a compromise for successful distance learning. It could be highlighted the following disadvantages of distance learning: restrictions on direct communication between students and teachers, lack of students' direct access to the teacher, students' constant self-motivation during the distance learning, distance learning isolation, limitation of available special training courses to master specialization, the necessity for constant reliable access to the latest learning technologies and Internet, mandatory accreditation of distance learning educational programs, employment restrictions, unforeseen additional costs for distance education, restrictions on improving students' oral communication skills.

Restrictions on direct communication between students and teachers. Restrictions on direct communication between students and teachers. Of course, the distance 
learning does not provide direct communication between students and the teacher during the subject acquisition. We mean the teaching atmosphere of teaching and perception in the classroom: the ability of holding themselves during the dialogue conversation and mastering the psychological state during a face-to-face interview, including answers to questions and coverage of educational material. Yes, there is a chat on distance learning platforms that allows you to send messages and highlight your opinion both in writing and orally using technical devices, but there is no machine of modern technology with the latest equipment for transmitting information, that can replace human direct communication, transmit the atmosphere of fulltime learning in the classroom, the psychological state of students when they meet each other and answering the questions. Thus, the restriction of direct communication between students and lecturers in distance learning causes students to fear losing contact with the teacher, in particular to ask him questions during the learning process in case of unclear material or after the lessons to find out the information about subject learning, so as this can be done in a traditional learning system.

I. G. Vlasenko notes that with long-term distance learning, students cease to properly form their thoughts, express themselves and lead a discussion (Vlasenko, 2017 , c. 12). This indicates that students are limited in communication with the lecturers, there is a lack of dialogues speech during the discussion of educational situations, which is inherent in the traditional higher education system.

Lack of students' direct access to the teacher. In our study, we distinguish the direct access to the teacher to receive his/her instructions, guidelines and feedback, when there is a face-to-face dialogue in the classroom and the immediate feedback between lecturers and students during the learning teaching subject. Direct access indicates the communication between students and the teacher during the acquisition of studying the material, in particular to diagnose the quality level of their acquired knowledge in the classroom, because you can put the questions to students or offer informal test work for a quick assessment. Thus, diagnosing the students' quality level can take place in the classroom immediately and at the same time assess performance. Students can find out problems from the studying material and get answers to their questions at once.

In the process of distance learning, students do not have the direct access to the lecturers, because they have to wait for the teacher's answers until he/she checks their work and sends points as a result of determining their knowledge quality level. Typically, students' papers are emailed to the teacher, then they are evaluated and with helping the feedback are sent back to the students. Having taken the modern learning technologies, students can get the results immediately, but this requires appropriate tests and programmed answers, but not all distance learning platforms are provided with such function. Of course, the oral answers to questions can also be sent by voice, but they all require the appropriate knowledge, skills and abilities to properly record and reproduce the sound. Thus, in the process of distance learning you have to communicate with the help of special technical means, and for such communication students with the teacher need to have a little more time to listen to the recording, write a new message, send it to the teacher and wait for answers. It could be said about the intelligence and awareness of our Ukrainian students, they have the opportunity and time to consult with classmates, find answers in the textbook and on the Internet, as student feedback from the teacher does not require an immediate response, including face-to-face or direct communication with him/her. Thus, we can say that students have no direct access to the teacher in the process of distance learning.

Students' constant self-motivation during the distance learning. Students' constant self-motivation during the distance learning. The distance learning is a way to get higher education at a distance with the help of modern information and computer technologies. The students of undergraduate courses are already trying to find a job in the labor market and start their work, so for them distance learning is a way to get higher education without leaving the job. It is important for them to study at a convenient time, but such an approach can lead to the educational material acquisitions unsystematically, to the tendency of postponing the unpleasant tasks, namely to do homework later, when there is inspiration and desire to do them, because they have got more important things for doing and they bring more satisfaction and quick results.

I. G. Vlasenko emphasizes well that the opportunity to learn at the convenient time can become not a systematic learning, but a constant procrastination of this activity (Vlasenko, 2017, c. 12). This approach to the learning subjects study, to some extent resembles distance learning. Because distance learning is flexible, it requires good organization, planning of the educational process, responsible work in the study of educational material and constant self-motivation, because without it not all students can perform exactly the necessary tasks for thorough mastering of the discipline consciously, productively and work with maximum dedication. Thus, students' self-motivation is a constant and dynamic process that determines their organization, activity, perseverance, ability to thoroughly the subject studying and encourages them to perform various types of tasks, mastering educational material, finding modern educational information to improve self-education and improve knowledge and skills, that are necessary to achieve the goals of the chosen future profession.

Distance learning isolation. The distance learning is an isolated learning despite the fact that we are in a virtual audience filled with students and the dynamics of interaction with them changes with the improvement of subject curricula, improving computer and information technology, improving the quality of online education. Although students are somewhat detached from the traditional form of education, they have the opportunity to send emails, post messages on bulletin boards, participate in online conferences and group online discussions.

We'd like to underline that the teacher does not sit in front of the students and does not give some instructions face to face, but they still need to complete tasks on time and send answers, to master the material, because the certain deadlines are fixed in schedules. It can be underlined, that students should be organized and pay 
more attention to self-education, improving the quality of knowledge, skills, abilities. That is why isolated distance learning is best suited for mature students who cannot afford traditional learning.

Isolated distance learning at higher learning institutions is the acquisition of education in case of students' inability to attend the universities, namely due to illness; long-term business trips or travels; participation in sports and art programs, including contests, competitions, etc. In the case when the learning institution does not provide qualified subject teaching in the chosen specialty, so most of the time students are spending in libraries to gain knowledge and study the materials independently.

Limitation of available special training courses to master specialization. All the necessary special training courses to master a particular specialty and specialization are not always offered in distance learning education. Students who study according to the relevant program and gain knowledge of higher education, they may not have all the necessary special courses available in distance learning for a thorough of study subject and mastery of highly specialized latest knowledge in the specialty, the formation of relevant skills. Therefore, distance learning is not suitable for all specialties. The introduction of special courses at universities promotes the students' activity in the process of studying the academic subjects and mastery the educational material, stimulates them to research, to persistent independent work and improve the quality of self-education. It should be noted that the improvement of skills and students' abilities of not all specialties can be done remotely. For example: for students of philology, in particular English, we can prepare tasks to improve their skills in practice, namely to select texts for translation, create phonograms for the reproduction the foreign language, but it is difficult to come up with tasks for students of medical universities to improve skills of their practical activity remotely, as they constantly have to communicate with patients and find out the causes of their illness, make a diagnostic examination and operate. Thus, there are limitations on improving the students' skills of different specialties and specializations.

The necessity for constant reliable access to the latest learning technologies and Internet. Modern education requires the introduction of the latest learning technologies to improve the quality of students' knowledge level, skills and abilities, to expand international and educational ties of the university, to accelerate its entry into the scientific and educational space. At the same time, computer technology and the Internet provide teachers with new opportunities, allowing students to enjoy the exciting process of learning about the nature mysteries and scientific discoveries. The learning process using the latest technology and the Internet causes emotional uplift in students, even those who have learning difficulties are willing to work with a computer. However, the computer cannot replace the teacher, his/her ability to teach the subject and have communication with students, so it only complements the teacher and is a unique tool that allows communication in e-mail or in real time. It is important in the process of distance learning to have constant reliable access to the latest learning technologies and the Internet so teachers and as students. Technical failures, ignorance of the latest learning technologies and inability to work with technical equipment, including computers, can cause stress and frustration in mastering the material, because due to computers and the Internet, students transmit their tasks and presentations, search necessary information for a thorough subject study. For example, online courses require a computer with Internet access. All of students and teachers must have a media player for the CD or DVD course. Currently, not all higher learning institutions are technically prepared for distance studying, so lectures and seminars are held using Office 365, Google Classroom, and the quality knowledge level, skills and abilities are assessed through the text tests, project presentations and research reports: social networks, including Moodle, Zoom, Skype, Viber, Telegram Messenger.

Therefore, teachers and students must be familiar with the latest learning technologies, have computer literacy, be able to work with technical equipment, have constant reliable access to computers and the Internet necessary to meet the requirements of a special course in distance learning subjects.

Mandatory accreditation of distance learning education programs. Accreditation of education programs is an assessment of the education program quality and education activities of higher learning institutions according to this program, in particular with the higher education standards, ability to meet the standards requirements, as well as achieving the stated learning outcomes in accordance with the criteria (Regulations on accreditation of educational programs, which provide training for applicants for higher education, 2019). As learning institutions operate in the distance learning mode, it is important that education programs and working of distance learning curricula meet the requirements of the higher education standards and ensure the education activities quality. If there is no accreditation of the distance learning curriculum, then there is a high risk that the school may issue fraudulent, invalid diplomas and they will not be recognized by employers in the labor market in the country and abroad. Accreditation of learning programs is one of the main requirements for ensuring the education quality and the realization of students' rights to receive it, ownership regardless and management areas. Thus, the presence of a document on the curriculum accreditation is the main proof of the learning institution rights to legally provide education services to students, including issuing a diploma certifying of the higher education completion in accordance with legal requirements and obtaining the chosen specialty and specialization.

Employment restrictions. Nowadays, employers are trying to hire professionals who have received an education certificate with a certain specialty and specialization. Some of them arrange interviews to find out the knowledge quality level, skills, abilities of the future employee. Employers are interested in the prosperity of their corporation, firm, enterprise, so they arrange competitions, various types of tests for candidates who would like to occupy a certain particular position. Most employers recognize distance learning, including acquired skills in the chosen specialty. However, some employers are skeptical about distance learning, so they set conditions for competitors to have work experience, preferably in the activity direction of a 
corporation, firm, enterprise where a specialist is hired. Students are free to choose a work place, but if they want to work for a particular employer after graduation, then they must be sure that they will be hired. Therefore, it is desirable to negotiate in advance with employers, because they hire specialists and they are responsible for the wages payment and its calculation, as well as for withholding and payment of personal income tax to the budget, contributions to the payroll, and other responsibilities provided by law.

Unforeseen additional costs for distance education. It is important to build a modern higher education, in particular distance education, in the context of civilized development and international requirements for education in the XXI century. Currently, there are public and private higher learning institutions that implement distance education, providing funding from state or local budgets, as well as from other sources not prohibited by law. Due to the limited state funding, higher learning institutions have increased the provision of paid educational services, so students have become a major contributor to the budgets of these education institutions, including universities.

Currently, distance education is developing very actively and provides an opportunity to obtain the necessary knowledge remotely from the higher learning institutions. Thus, students have the opportunity to work in different parts of the country and fulfill the relevant mission: to perform military service on a ship or in a military unit, to be on a long business trip or vacation, to participate in competitions or contests, etc. That is why teachers have to send teaching materials in advance so that students receive them on time for completing the subjects' tasks and have time to send them by the deadline, and this leads to additional costs and maintenance (Top 10 Distance Learning Disadvantages). The distance learning process is based on the use of various new educational technologies, including computers, but it is not always possible to use them for doing the learning tasks and send them back with completed tasks on time, that's why there are some additional financial costs for distance education.

Restrictions on improving students' oral communication skills. Restrictions on improving students' oral communication skills. Communication in the process of studying subjects always brings emotions of joy, excitement, irritation, suffering to both teachers and students, and is an integral condition of pedagogical activity in the subject teaching and mastering the material. The purpose of oral communication in the process of learning subject is the exchange of information various types, achieving mutual understanding and ensuring interaction between teachers, colleagues, students. The distance learning education does not allow students to work on oral communication skills and they do not get the verbal interaction practice with teachers and other students, because they use technical speaking means in the communication process, which do not always accurately convey sounds, words. The latest educational technologies can be used as an aid to information transfer for a thorough subject study, but to improve the oral communication skills, they cannot replace the teacher, his/her public speaking skills, communication skills in the subject teaching. In the course of communication, it is necessary to take into account that speech skills are mechanical in nature, and communication skills are creative, so the improvement of skills and abilities of students' oral communication is individual and gradual.

Based on the above, we draw the following conclusions. Without denying the benefits of distance learning, it is necessary to pay more attention to the adults' education in computer literacy, including students, teachers, parents. Modern education requires a thorough the academic subject mastering, therefore, it is necessary to improve the distance learning structure to achieve greater efficiency in learning. Therefore, it is desirable to use practical video tutorials in the process of distance learning education, to develop additional special courses for mastering academic and elective courses, and learning courses of recollection the students' knowledge missing level, and it is desirable to introduce a rating system to assess the quality of students' knowledge level.

\section{REFERENCES}

Vlasenko, I. H. (2017). Vprovadzhennia dystantsiinoho navchannia - vymoha suchasnosti [Implementation of distance learning education - a requirement of modernity]. Dystantsiine navchannia yak suchasna osvitnia tekhnolohiia: materialy mizhvuzivskoho vebinaru (m. Vinnytsia, 31 bereznia 2017 r.) / vidp. red. L. B. Lishchynska. Vinnytsia: VTEI KNTEU. 102 s. URL: http://www.vtei.com. ua/images/VN/31_03.pdf (data zvernennia: 05.02.2021).

Polozhennia pro akredytatsiiu osvitnikh prohram, za yakymy zdiisniuietsia pidhotovka zdobuvachiv vyshchoi osvity [Regulations on accreditation of educational programs, which provide training for applicants for higher education]: nakaz Ministerstva osvity i nauky Ukrainy vid 11 lypnia 2019 r. № 977. URL: https://zakon.rada.gov.ua/ laws/show/z0880-19\#Text (data zvernennia: 10.02.2021).

Top 10 Distance Learning Disadvantages [Top 10 Distance Learning Disadvantages]. URL: https://www. streetdirectory.com/travel_guide/20432/education/top_10 distance_learning_disadvantages.html (data zvernennia: 07.02.2021).

\section{СПИСОК ВИКОРИСТАНОЇ ЛІТЕРАТУРИ}

Власенко, І. Г. (2017). Впровадження дистанційного навчання - вимога сучасності. Дистанційне навчання як сучасна освітня технологія: матеріали міжвузівського вебінару (м. Вінниця, 31 березня 2017 р.) / відп. ред. Л. Б. Ліщинська. Вінниця: ВТЕІ КНТЕУ. 102 с. URL: http://www.vtei.com.ua/images/VN/31_03.pdf (дата звернення: 05.02.2021).

Положення про акредитацію освітніх програм, за якими здійснюється підготовка здобувачів вищої освіти: наказ Міністерства освіти і науки України від 11 липня 2019 р. № 977. URL: https://zakon.rada.gov.ua/ laws/show/z0880-19\#Техt (дата звернення: 10.02.2021).

Top 10 Distance Learning Disadvantages. URL: https://www.streetdirectory.com/travel guide/20432/ education/top_10_distance_learning_disadvantages.html (дата звернення: 07.02.2021).

Дата надходження до редакиії: 21.03.2021 p. 